\title{
THOUGHTFUL LEARNING: A CASE STUDY USING A SET OF PRINCIPLES INSPIRED FROM THE ISLAMIC TRADITIONS
}

\author{
Salam Abdallah ${ }^{*}$
}

\begin{abstract}
Educational institutions in the Middle East are facing the challenges for providing meaningful learning approaches for students in order for them to meet the challenges of everyday life. The current trend in education is to move away from traditional methods of covering contents and to concentrate on processes that lead to learning and discovering of knowledge. This study proposes a set of principles that were inspired by reflecting on one of the greatest Traditions of the Prophet Muhammad, known as the 'Hadith of Jabrā'îl' (Gabriel). The learning model used within a blended teaching environment consists of face-to-face and online learning activities. The model was used for assisting adult students to attain a systemic thinking for understanding two subjects in information systems. This article is based on a qualitative research method to portray a personal reflection and experience on the teaching philosophy which has a positive impact on the lives of the students.
\end{abstract}

\section{Introduction}

There are a number of efforts across the Middle East to revive teaching and learning practices. This revival is being called for to deal with technological advancements and the emergence of globalisation. One of the approaches which is being widely expressed in these arenas is the 'Systemic Approach' (SA) to teaching and learning. The term 'systemic' means approaching matters holistically, and its way of thinking is called 'systems thinking'. 'Systems thinking' is a discipline for understanding wholes or systems and the interrelationships between their parts. ${ }^{2}$ To understand a particular system one needs to see how this system fits into another larger system.

In an educational setting, 'systems thinking' requires those who are involved in either teaching or learning to zoom out in order to see the whole (subject) and the connectedness between its parts (topics). Studying topics independently will not provide in-depth understanding of the subject as a whole and it will preclude the

* Dr Salam Abdallah is Assistant Professor of Information Systems at Abu Dhabi University, United Arab Emirates. 
integration and transfer of knowledge to other subjects or to the workplace of the learner. Senge argues that:

From an early age, we are taught to break apart problems, to fragment the work. That apparently makes complex tasks and subjects more manageable, but we pay a hidden, enormous price. We can no longer see the consequences of our actions: we lose our intrinsic sense of connection to a larger whole. Systems thinking requires also knowledge and tools to make or uncover patterns to make the whole observable. ${ }^{3}$

Making the whole observable has become an important concept for teaching adult students. The teaching of adults requires the adoption of open-ended systems as opposed to closed-systems or mechanistic thinking. The learning environment of adults is seen as non-linear and/or organic thinking. ${ }^{4}$ Adults are usually armed with prior declarative and procedural knowledge and they continue to adapt and add to their knowledge-base as they interact with their educational institution, society and the workplace. Therefore, the teaching approaches for adults in a formal environment need to be nourished in a different way. ${ }^{5}$ Learning needs to be active in order to motivate adult learners. Adults need to see their learning as meaningful and benefiting them. ${ }^{6}$ Bork $^{7}$ argues that "the usual threats of the classroom, mostly centring on tests and grades, are no longer reasonable, and probably never were. The units must be designed to keep students working at difficult learning tasks." Adult students need to be actively engaged in skills that build their capacity to solve problems and to look for connections and patterns in order to construct a shared worldview of the discipline of their specialisation. Students need to reflect on real life issues and raise critical thinking questions which help students to see how they fit into this world. Capra ${ }^{8}$ argues that students need to make several shifts to enable them to see the whole. This kind of understanding and thinking requires frameworks, tools and principles to assist educators to innovate methods and techniques in a way to allow students to transform their way of thinking.

In summary, there is a need to shift our curriculum development efforts from the content to the process: a teaching process which integrates 'systemic thinking' into the curriculum. Students need to adapt new ways of thinking and become reflective students and go beyond memorisation of unrelated facts. This process of change requires innovative methods and techniques to transform students from being passive observers to active learners.

\section{Motivation}

What has motivated me to write this article is the observation made in changing the mode of instructions from passive to active. This mode has resulted in positive students' change of behaviour and action. Students became motivated and started to 
enjoy learning by thinking. My adopted model of learning was greatly influenced by my reflection on one of the greatest traditions of Prophet Muhammad, known as the 'Hadīth of Jabrā'îl', narrated by 'Umar.' This learning model has dictated my way of thinking and has been used within a blended teaching environment consisting of face-to-face and online learning activities.

The following sections are a reflection of teaching approaches used on a group of postgraduate students at a university in Jordan. Students used these approaches to harness systems thinking to learning. The objective of this article is to encourage faculty members to deviate from the traditional rigidity of teaching and to adopt a more creative teaching approach. The emphasis of this article is on the process that led to change of attitude of students towards learning and not the actual methods used.

First, I will discuss the research method used followed by a discussion on a set of principles which influenced the adopted teaching environment. The implication of these principles will be discussed and supported by statements by the students before finally ending with a conclusion.

\section{Research Method}

As previously mentioned, this research is based on a 'qualitative case study' approach to understand the effects of various teaching approaches on supporting the thinking and learning of students. I wanted to examine if thinking helps students in understanding concepts and their relationships. In addition, I sought to see if thinking helps motivate self-learning and critical thinking; i.e. thinking that goes beyond what textbooks say. The case study method belongs to qualitative research methods, ${ }^{10}$ aiming at gaining insights rather than gathering statistically significant evidence. 'Qualitative research method' refers to the strategy for data collection and analysis. ${ }^{11}$ Theories developed using qualitative approaches are often more representative of the real world because they generate 'rich' data collected from the words, actions, and symbols (explicit and tacit knowledge) of people. Rich or qualitative data are the results of meaning allocated by people to events and objects. ${ }^{12}$ Throughout this article, I will support some of the arguments using the exact words taken from students who have expressed their feelings and opinions on the teaching process.

\section{Case Description}

The course participants were enrolled in master's degree courses at one of the Jordanian universities. Eighty adult students were attending either Management Information Systems or Electronic Commerce subjects. The students were 
postgraduates who were mostly working adults and mostly accustomed to teaching methods where the teacher is in the centre of the learning environment and totally in control. The instructions mode was in English, but students were allowed to express themselves in either Arabic or English. As mentioned earlier, the teaching approach was based on various, blended face-to-face, and online activities.

\section{Data Collection}

Data was collected at several stages over a period of two semesters. The method used for data collection was through asking online open-ended questions, which gave the students the opportunity to express their thoughts freely with no threats. I did not ask students about any specific part of the course. I asked students to list things that they liked about the course and also things that they disliked or would like to improve. I did not want to direct or influence the thinking of the students and I wanted their thoughts to come out freely. I have collected over one hundred statements that address various aspects of the student experience on learning through this blended environment. In addition, data was also collected through my observations of the students' behaviours and action and through informal class discussions immediately after carrying out exercises to see the effect of the learning approach. The data collected was in both Arabic and English. I also followed up on twenty students after three months of completing a course with me. I wanted to see if they had gained and applied thinking skills to their working life and in studying other subjects.

\section{Principles for Thoughtful Learning Foundation}

The epistemology for my teaching principles used in this case as mentioned previously was greatly influenced by reflecting on the 'Hadìth of Jabrā'îl' which was narrated on the authority of 'Umar, ${ }^{13}$ who said:

One day while we were sitting with the messenger of Allah there appeared before us a man whose clothes were exceedingly white and whose hair was exceedingly black; no signs of journeying were to be seen on him and none of us knew him. He walked up and sat down by the Prophet. Resting his knees against his and placing the palms of his hands on his thighs, he said: "O Muhammed, tell me about Islam." The messenger of Allah said: "Islam is to testify that there is no god but Allah and Muhammed is the messenger of Allah, to perform the prayers, to pay the zakat [zakāh], to fast in Ramadhan, and to make the pilgrimage to the House if you are able to do so." He said: "You have spoken rightly," and we were amazed at him asking him and saying that he had spoken rightly. He said: "Then tell me about eman [īmān]." He said: "It is to believe in Allah, His angels, His books, 
His messengers, and the Last Day, and to believe in divine destiny, both the good and the evil thereof." He said: "You have spoken rightly." He said: "Then tell me about ehsan [ihsaan]." He said: "It is to worship Allah as though you are seeing Him, and while you see Him not yet truly He sees you." He said: "Then tell me about the Hour." He said: "The one questioned about it knows no better than the questioner." He said: "Then tell me about its signs." He said: "That the slave-girl will give birth to her mistress and that you will see the barefooted, naked, destitute herdsman competing in constructing lofty buildings." Then he took himself off and I stayed for a time. Then he said: "O Omar, do you know who the questioner was?" I said: "Allah and His messenger know best." He said: "He was Jebreel [Jabrā'îl, Gabriel], who came to you to teach you your religion."

Many Islamic scholars have declared this narration as one of the most authentic and important hadith, because it covers all the fundamentals and concepts of the religion of Islam, which was indicated at the end of the hadith in the phrase "came to you to teach you your religion". The event of this narration occurred towards the end of the life of Muhammad, and the Companions (al-ṣahābah) learned the content of this narration in fragments over many years.

The hadith has provided a systemic approach to Islam and its various related segments. It has identified what makes up a complete discipline, i.e. foundational concepts, beliefs, way of conduct (ihsān), there are unknown matters, and the world is dynamic with indicators to mark its end. The hadith highlights the value of having a holistic understanding. The narration did not only provide a conceptual view of what is Islam but also provided some fundamental ways of teaching it, as mentioned at the end of the hadìth, "came to teach". This statement implies that certain teaching methods are embedded in the narration, which is used to impart the knowledge of this important lesson.

Six principles were seen as fundamental in this narration for creating a thinking and thoughtful learning environment (see Table 1). What follows is an explanation of these principles in relation to the 'Hadìth of Jabrā' '̄l'.

Table 1 A Set of Principles for Thoughtful Learning

\begin{tabular}{ll}
\hline Principle & Description \\
\hline Dialogue & Creating conversation through questions, answers and feedback. \\
Observation & Awareness of things, building relations and recognising problems. \\
Contextualisation & Putting the parts into context or into a larger context. \\
Conceptualisation & Recognise and develop concepts. \\
Authenticity & Act right and truly. \\
Lifelong learning & Learning as a way of life. \\
\hline
\end{tabular}




\section{Principle of Dialogue}

One of the greatest lessons was conveyed to the Companions through a dialogue between Jabrā'̄̄l and Muhammad, especially a dialogue that is accompanied by questions and answers. Raising the right sequence of questions generated the 'whole' concept of Islam. Scholars have said that asking the correct question is half of the knowledge. ${ }^{14}$ Thinking is an act 'not' driven by answers but by good critical questions. A good dialogue is a dialogue that also provides feedback to enforce quality learning. Reflecting back on the hadìth, Jabrā'îl said several times of the Prophet's answers: "You have spoken rightly".

\section{Principle of Observation}

Good observation requires the use of senses and experience to observe before making judgment and to look for meanings. The first stage for observation is an awareness of facts such as the statement made by the companion describing the strange man "whose clothes were exceedingly white and whose hair was exceedingly black". The second stage includes making connections and setting up relationships between disparate facts based on existing knowledge. This stage was demonstrated in the hadith when the companion said "none of us knew him" so as if he was from out of town but at the same time "no signs of journeying were to be seen on him". Capra ${ }^{15}$ argues that "the world is a world of relations, and within these relationships we draw circles around a certain pattern", and we say "well, this is what I call an object". We need to teach students the process of how things interrelate.

The term 'thinking', which translates as tafakkur in Arabic, has a combined meaning of think and reflect. On many occasions the Qur'ān calls upon man to think and reflect on systems in order to see relationships between the various parts, such as sky and earth, day and night, man and woman. ${ }^{16}$ Ibn Khaldūn (d. 1406) argued that thinking is a natural gift from Allah and a desired state to rise to a higher order of living. ${ }^{17}$

A higher stage of observation is reflection, and this occurred in the dialogue when Jabrā'1̄l replied "You have spoken rightly" to Muhammad after answering several questions. The companions "were amazed at him asking him and saying that he had spoken rightly". This higher stage of reflection requires a person to determine problematic issues, which can only be recognised through experience. Problems at this stage require further information or research to be resolved. In the case of the hadìth, the problem was resolved when Muhammad provided more information to the companion, by saying "He was Jabrā'1̄l [Gabriel], who came to you to teach you your religion." 


\section{Principle of Conceptualisation}

Conceptualisation is an abstract and simplified representation of certain knowledge. Muhammad in this hadìth did not provide details of islām, ìmān, and iḥsān; he only provided their concepts and their pertaining principles. The relationship between these concepts leads to holistic understanding of the Religion of Islam. I have learned from this hadith the importance of conceptualisation as a way of conveying knowledge in order to see the whole.

Conceptualisation is a mental model that we have 'in our heads' constructed from knowledge and experience. ${ }^{18}$ If we want to help students become critical thinkers, we must help them to recognise good concepts and build their skills to create their own concepts that explain their own knowledge and experiences. We should encourage concepts and not memorisation of facts. They must be able to build connections and relations between the various concepts in order to see the whole. People act upon their mental models that they have constructed over many years. Providing students with distorted concepts can affect their understanding and their useful contribution to society. Therefore, critical questioning of concepts needs to be encouraged in order to understand their implications on other concepts and in different environments.

\section{Principle of Contextualisation}

Capra $^{19}$ argues that in order to understand something, you don't take it apart; you put it into a larger context. In order to understand the purpose of this hadith, it requires from the reader to have critical reflection on the social and historical background of the setting. For example we need to know who is Muhammad, Jabrā's̄l, and the Companions, and what are their characteristics. When was it narrated? Therefore putting the narration in its historical context provides more sense to the reader. It will provide depth and breadth to its meaning as opposed to abstract interpretations. Van Oers ${ }^{20}$ adds that in order to arrive at a coherent meaning "essentially depends on some sort of surroundings". Hirsch ${ }^{21}$ acknowledges that understanding the context "narrows the meaning probabilities for the particular word sequence; otherwise, interpretation would be hopeless". Students have to learn how to put concepts in different contexts in order for them to have detailed understanding of the concept itself.

\section{Principle of Lifelong Learning}

Lifelong learning is a process that can take place in different contexts formally and informally. We know from the Islamic history that the Prophet taught his companions formally (in mosques) and informally while interacting with the companions in their daily activities and other events. As I have mentioned earlier, the hadith was one of the important lessons given to the companions. The lesson was given in 
an informal setting, as stated by the hadìth: "One day while we were sitting with the messenger". Another observation from the hadìth is that the companions were adults who were still learning.

Lifelong learning occurs mostly during informal practice. Much of what we learn, both in and out of the workplace, occurs during informal practice. ${ }^{22} \mathrm{Conlon}^{23}$ cites a survey by Marsick and Volpe, ${ }^{24}$ claiming that only 20 per cent of employees learn through formalised education. The study also found that employees developed their own personal strategies for asking questions, listening, observing, reading, and reflecting on their work environment. Therefore, it makes sense to simulate the informal environment to prepare students for lifelong learning: an environment that encourages active learning, participative approaches and which allows the student to be at the centre of learning and not the teacher. Probably the most important skill students should develop is the ability to take responsibility for their own learning and to sustain intellectual curiosity.

\section{Principle of Authenticity}

This principle is a quality characteristic of the teacher in being authentic, trustworthy and genuine. This principle is foundational to the other principles. The authentic teacher is the person who can make learning more effective by providing a comfortable environment for students to open up, become active, reflective and expressive. Critical thinking cannot occur in an oppressed environment and without the principle of authenticity. Demetrious, ${ }^{25}$ citing Brookfield, ${ }^{26}$ proposes that "being an authentic teacher includes making sure our behaviours are congruent with our words, admitting we do not have all the answers and can make mistakes, building trust with students through revealing personal aspects of ourselves and our experiences, and respecting students as people". This principle is needed to build trust between the teacher and students. Cranton and Carusetta ${ }^{27}$ defined authenticity as having four parts: being genuine, showing consistency between values and actions, relating to others so as to encourage their authenticity, and living a critical life.

Authenticity was demonstrated in the hadìth by the physical and vocal engagement between Muhammad and Jabrā'îl: "He walked up and sat down by the Prophet. Resting his knees against his and placing the palms of his hands on his thighs, he said: 'O Muhammad'." The physical touching and calling of the name are ways of making intimacy, respect, and personalisation.

Students and teachers should also be allowed to say "I do not know" when a question is difficult to answer. When Muhammad was asked when is the Day of Judgment he replied "I do not know." The idea of not knowing everything does relieve teachers and students from the stress of having to know everything.

Students also learn a great deal from the ethical conduct of teachers, their ways of thinking and the tacit knowledge they exhibit. Teachers are role models. Teachers 
therefore should exhibit excellence in their behaviour and action. Islamic scholars described the word ihsān in the hadith (act right and truly) as the highest level of self application in Islam. The opposite of $i h s \bar{a} n$ is abuse. I $h s \bar{a} n$ also includes sincerity, self-accountability, perfecting actions and behaviour. One can best learn the meaning of authenticity through close examination of the conduct of Muhammad, who was sent for the purpose of "the perfection of moral goods" and who spent more than twenty years teaching.

These six principles helped me to assist students to learn thoughtfully through observation, proper dialogue, seeing concepts in their context and all this occurring in a respectful and informal environment. These principles were interwoven into a blended learning environment incorporating a variety of activities.

\section{A Blended Thoughtful Learning Environment}

To optimise the thinking capacities of students I have used a blended mix of learning environments between face-to-face and online learning environment: An environment that will encourage learning by doing (see Table 2).

Table 2 Blended Thoughtful Learning Activities

\begin{tabular}{ll}
\hline Face-to-Face & Online Activities \\
\hline Mini lectures & Discussion board \\
Mini cases & WebBlog \\
Student presentation & Wiki \\
Written assignments & Glossary \\
Topic impact & Internal mail \\
Raising critical thinking questions & \\
\hline
\end{tabular}

The blended environment of face-to-face and online learning has created a thoughtful platform for students. Thoughtful because it made them think through a variety of activities. Kraak ${ }^{28}$ argues that thinking is "an important, perhaps the most important of all present time's educational tasks". ${ }^{29}$ Bruning ${ }^{30}$ states that critical thinking is essential for adult students since they value democratic tradition where people have a participatory role in making decisions based on the outcome of critical thinking and where alternative solutions are examined from their various dimensions. Therefore, critical thinking is a process with a purpose. Adults have the capability to research circumstance and challenge their assumptions. They use their prior knowledge to make critical judgments on practical applications. Students need activities that will stimulate their cognitive process to reflect and give them a higher order of learning. ${ }^{31}$ Such a process is highly stimulated when it is exercised through 
a higher order of interaction through collaboration in communities. The process of creating of knowledge is the focus and not the content. It involves discovering how to analyse, synthesise, make judgments, and create and apply new knowledge to real-world situations. ${ }^{32}$ Students who are equipped with these skills will be provided with lifelong learning capabilities.

\section{Face-to-Face Learning Activities}

In this learning environment, I have combined several approaches to assist students with a rich environment for learning in order to see the whole picture.

Mini lectures: Lectures do not exceed 45 minutes. They are divided into segments, and the remaining hour and a half is spent with discussions and other activities. Lectures are conducted using PowerPoint and 'data' show. Discussions are encouraged in between segments. I usually project key statements on the screen for students to reflect on and to express their understandings and opinion.

Mini case studies: The use of cases which are mostly related to the local and regional markets. Cases were retrieved from Arabic news websites. Additional cases were taken from foreign contexts to demonstrate successful and creative solutions.

Student presentations: To develop student communication skills, they were asked to carry out presentations. Students had the choice to either critically analyse an academic paper, to discuss a successful case, to evaluate websites according to set guidelines, to bring in their own experience to the class or to select any topic of their interest. Presentations were usually followed by questions and answers.

Written assignments: Students were required to submit written assignments on their presentation in two or three pages with references. This assignment was used to build structuring and writing of good reports.

Topic impact: At the end of each session, the students were required to state one topic which they felt is important, and they also had to state 'why' they thought it is important. I was particularly interested in the 'why'.

Raising critical-thinking questions: The students were required to raise a criticalthinking question which was related to a certain topic. The critical question usually initiated student-to-student discussion.

\section{Online Learning Activities}

For the online learning environment, I have used Moodle, ${ }^{33}$ a Learning Management System (LMS), to further unleash the thinking process of the students. Moodle was installed on a website to specifically serve my teaching courses. The use of LMS has become an accepted practice in Western universities to deliver e-learning or 
support blended-learning activities (online and face-to-face learning). LMS can link class and home education through computer technology in meaningful ways.

Moodle is Free and Open Source (FOS) and downloadable from the internet. The learning philosophy of Moodle is based on the concept of "social constructionist pedagogy". This concept is based on the belief that students' learning is strengthened by applying prior knowledge and principles to a new environment resulting in construction of new knowledge. ${ }^{34}$ This philosophy is also based on the belief that if students construct knowledge for others to read, it will result in a more effective way of remembering knowledge. Students become teachers and learners at the same time. Therefore, students need to connect to other students and become a community of practice to facilitate knowledge sharing. Through this community, students will be motivated to learn and collaborate on knowledge building and exchanging. The tools provided by Moodle give students an opportunity to reflect on knowledge outside the formal class. The teacher's role in this type of pedagogy is that of a facilitator, directing students to sources of knowledge and moderating the online activities. Moodle is also used as a course portal to distribute lecture notes, notify students of coming events, describe assignments, submit assignments, take tests, and other constructivist tools, such as:

Discussion board: Student postings of questions and opinions, allowing students to respond. I have used the discussion board for students to post their critical-thinking questions and allow other students to respond in their own opinions and words in their own time. This allowed students to research their answers before responding.

WebBlog: Individual writing and reading environment, providing the ability for other students to comment on the content of the written text. I have used this only on one occasion. One of the students had to go overseas for a business trip to install and implement a software application and was unable to take the mid-term assessment. He was given the assignment to write a daily journal for a week and to reflect on his work activities and on the theories and issues which were discussed in class. The objective was to relate practice to theory.

Wiki: Collaborative writing environments which have a shared goal. Students collaborate on writing a single document with multiple pages. A 'wiki' provides individual revision of history and to view recent changes. A teacher can track the contribution of each student. The content of a wiki document is editable by all students. ${ }^{35}$ The students used the 'wiki' to write up teaching notes in Arabic related to the subject being taught. The objective of the 'wiki' document was for it to be posted publicly online to be used by anyone who is studying similar subjects as a contribution to their community. 
Glossary: The students collaborate to build an Arabic glossary related to the topics being studied.

Internal mail: Private internal email was used by the students to communicate.

Moodle gave me a 'closed loop' for students to have privacy and I had full control of its customisation and administration. The next section will argue on the value of some of these activities and the proposed six principles supported by students' statements.

\section{Discussions}

One of my students has mentioned that "You know where you are taking us." Teaching and learning is like taking a journey; it can be eventful, enjoyable and memorable. One student said, "Many years later, I will remember all about this subject." If the journey is enjoyable, you want to do it again. Another student, after completion of the course, said, "I hope all the subjects I'll take in the university are like the MIS course", and many others have expressed the journey (learning) was enjoyable. For example:

The class was interesting and useful [...]. I enjoy it. [...] Your lecture deserves that I wake up at 7 o'clock in the morning each Saturday.

Students who miss class do not miss out on the content of topics because they can get it from text books, but they will miss out on the shared experience. The sharing of experience is the journey that they had enjoyed, one that was guided through the application of six principles: dialogue, observation, contextualisation, conceptualisation, authenticity, and preparing for lifelong learning.

The application of the principle of dialogue was the ice breaker prompting students to ask questions. Dialogue is not a one-way channel; it is multi-channel teacher-to-student, student-to-teacher, and student-to-student. Statements like these highlight how much students valued dialoguing.:

The way you are running the course: encourage students participation, open to suggestions [...] realised the importance of participation [...]. Discussions in class is good and served to make the dry topics more palatable [...]. I like the open communication.

The blended learning environment has provided an ideal situation for students and me to connect, to dialogue and to raise our awareness, and to think critically about the various teaching topics. The raising of critical-thinking questions in class has created a climate for fruitful dialogue. It allowed students to reflect and to freely express themselves. The use of the online discussion board to post the students' critical questions had a similar effect. Using online activities had a benefit of giving 
students more time to think, research, and reflect before posting their questions and answers. The use of the discussion board has allowed students to dialogue, converse and brainstorm on ideas, as expressed by one student: "This website is very useful for me, and the types of participation are very enjoyable, especially that I can share the opinions with others."

Online discussion is considered a useful way to generate learning dialogue between students, ${ }^{36}$ and it provides a useful strategy for critical thinking development, the encouragement of creativity, and reflective thinking, and it can lead to self-directed learning. ${ }^{37}$ Here are some of the statements from students on using the course website:

It allows us to interact with the instructor and colleagues in a better way... I like the new style (using web site) direct communication... the forum and using the moodle is a great idea [...]. I do like the idea of having a web site for the student opinion and forums [...]. I think the website is a good idea to improve our obligation according (to) the course which we are studying, also it support us with interactive method.

Students who are able to generate good questions go through a process of thinking and learning. In preparation for the mid-term assessment, I have asked students to generate three questions along with their own answers. I have also asked them to post their questions on the online discussion board so that students can think about other students' questions and learn from each other's style of thinking, as well as to avoid repeated questions. Students had mentioned that they liked "the idea that the students participate in the exam" because it focuses on what is important as expressed by one student "emphasizing on foundations and primary themes" and another student liked the idea of raising their own exam question because in that way "we will be tested on what is important for us". Through this exercise, students took part in a democratic choice which gave them a sense of responsibility for their own learning.

To assist students in understanding the principle of conceptualisation, I have used the questions that were generated by them for the mid-term assessment as an activity to draw concept maps. The activity was to take the questions which seemed to be at first impression unrelated and to build concepts and relationships between the concepts and finally to draw a concept map. The activity was carried out in teams of three or four students. The teams read each question, decided on its theme, and placed it on the concept map. Each group then presented their map to the class. I followed this activity with a class discussion on the value of this exercise. This was the first time students carried out such an exercise and they were astonished at how a set of large questions can be conceptualised and easily related to each other. They were also amazed at the amount of learning that they have gained without them realising it. The use of concept maps gave students an in-depth understanding of topics and their relations. Through conceptualisation, students have learned and 
knowledge was ingrained using such an exercise. The students also appreciated the value of teamwork. Again, that is something that we do very little in our class rooms, where we often concentrate more on individualism rather than collectivism.

In this study, the feedback was provided collaboratively and continuously; I gave feedback to the students and the students gave me their feedback about the process and the content of the course. When there is an individual issue, feedback is usually relayed by email or during class sessions when it is a group issue.

The use of email was encouraged between students and myself. The idea of using communication by email took a long time to get rolling. But once students got a feel for its value and how quickly they could get a response to their questions, they became frequent users.

The different activities throughout this course helped students to create a dialogue to learn. As one student expressed it: "People are able to learn more and have the ability to communicant better."

The principle of observation was accomplished in my teaching method through case studies and class presentation. The value of cases/stories cannot be underestimated; stories are one of the powerful teaching approaches used in the Qur'ān. The cases were mostly taken from local and regional applications. Cases were usually distributed in class for students to read, observe and reflect on the words and the events given in each case. In-depth case discussion followed to allow students to communicate their reflections on the case and to make connections to the various topics that were covered in the current or previous classes.

Students were given larger cases to present in front of the class. The students also observe and reflect on what the presenter is trying to communicate and learn from his style. The value of the presentations was expressed in a statement from a student: "Giving every student a topic or two during the course to explain to colleagues has contributed to make students interact with the course and communicate information to colleagues in a summarised and clear form." Another student had a similar feeling: "I liked the idea of having a case study then we discuss it in the class, it was very interesting and it helped us a lot in studying this course!"

Students need to understand the principle of context to allow them to critically evaluate issues, events, and actions. For example, when students examine a case taken from a western society they have to understand it in the context of its origin. This will help students to understand the case holistically; i.e. its content and its environment. Understanding cases in their context will also help students to realise the implications when transferring a solution to a different context.

One should not simply apply uncritically the theories of the West to Arab and Islamic culture. There are some major civilisational differences. Some Muslims are not making the effort to take knowledge given in Western textbooks and place it into a Middle Eastern context. With this limited approach we convey the (wrong) 
message to students that we are imitators and not innovators, and this may prohibit creative thinking on our part (teachers and students). With the application of the context, students started to realise the limitations of culture and technology, but also became aware of global issues of which we have to be a part.

The principle of authenticity is also important. An oppressing environment discourages students from the will of free thinking. Authenticity is a personal conduct that I became aware of to ensure that my behaviour is professional and does not offend. I had to practise what I had preached. Such attitude encourages a nourishing learning environment. I have used a variety of ways to place students in a comfortable, non-threatening and informal surrounding. The statements that have been collected from the students can explain what authenticity actually is:

Cares about the students, and willing to help anyone at anytime; always available to students [...] patience [...] social and technical support [...] manner to reach for all student by keeping them as friends not students [...]. Flexibility of instructor [...] asking if there is any question or comments [...] friendly way [...]. The flexibility in dealing with the instructor. I don't feel that there is any embarrassment from the doctor especially through the participation inside the class [...]. Good ethics (țayyib al-akhlāq) and style of treatment.

In one of my classes, I had about 28 students and one of them challenged me if I knew all their names. The students were amazed that I was able to mention every single name, although it took much effort to learn them all, but in doing so I have gained their respect and trust. During an informal conversation with one student, he mentioned to me that it is important for students to see the teachers putting effort into preparation.

Students had the option to also contact me freely by email and by mobile phone. The idea is that students need to feel that the teacher is always close when in need and it is part of building intimacy. Building intimacy between teachers and students is important, to allow students the comfort to think freely without prohibitions.

In the early stages of training students to speak their minds, one should not interrupt their contributions, even if they make no sense. While students are building their confidence in expressing themselves, the teacher may intervene and provide feedback in a gentle manner. A teacher needs to become aware of individual needs and to vary assignments according to the capabilities of the students. We should not view teaching as a production line for producing identical products.

The process of learning that a student takes with them after graduation is probably more important than the content itself. The application of lifelong learning principles is important to develop the thinking skills and motivate students to continue learning after graduation. Here are some statements by students which show that they have gained lifelong learning skills through the mentioned blended activities: 
Motivation to learn: "God-willing, I will keep on reading your website to develop myself more and more [...]. I no longer rely on textbooks; I look for other sources [...]. The approach has influenced the way I study for other subjects; I have started to study on a regular basis."

Thinking skills: "The key success factor in this course is how you taught me to think critically [...]. It increases the analytical thinking skills for the student and his ability of evaluating his mind power [...]. The information I got helped me in other subjects, like system analysis and design."

Communication skills: "It supports the learning skills of the student in both Arabic and English - and especially in English."

Personal development: "It increases the self-confidence which the student needs to support his personality in order to face the community and to socialise strongly with it" Technology skills: "It enhances my capabilities of using the internet."

It can be seen that a variety of skills were gained through the applications of simple but effective means of teaching. The above skills are transferable and can contribute to the lifelong learning of students. We should shift our focus from paying too much attention to teaching students to pass exams, to teaching students to become autonomous lifelong learners as a style of life.

Thinking holistically was the main purpose for the application of these principles. The purpose was to get students to think holistically and to see the interconnectedness between various topics and subjects. Part of this holistic view is the students themselves. It is important for students to discover their potential capabilities and to harness an environment of dialogue between themselves. The teaching approach used in this case was a balance between content and process in a comfortable learning environment. A variety of learning approaches was used to meet the diverse needs of students. The discussed approaches had assisted students to see the whole, its parts, and their relations. The following are some excerpts from the students' statements that indicate that students can value the idea of the 'whole':

However, the main thing here is that I understood this course as a whole, which means $\mathrm{Me}$ as a manager - God-willing - will benefit implementing IT in my firm's main departments... highlighting on many subjects completes somehow my knowledge about EC (electronic commerce) [...]. Linking issues together built a clear idea [...]. First, I found EC as one of my subjects and that I have to pass in order to finish my master's degree. But maybe now and with the end of the first period, I start looking at its content as the connecter between my other subjects. Especially MIS [...] made me look for matters as a one picture - a kind 
of bird view - which helps a lot to solve complicated problems [...]. Linking issues together built a clear idea. I try to relate what I have learned to what I do at work.

I will end this journey with another statement from one of my students, which may summarise poetically what I have been discussing:

Coming to lecture, from a far distance from Karak directly to the university is most of the time a picnic and a journey in eagerness to meet with loved ones and aiming for knowledge with a teacher and a mentor we respect.

This blended approach had a few drawbacks for some students, as expressed in their feedback. Attending a lecture in English was quite an issue for some students. Access to the internet was not always available to students from their homes and it also had cost implications. Most of the students were working adults and had limited time for carrying out the activities effectively.

\section{Conclusion}

I have presented six principles as a foundation for systems thinking to assist students to see the whole and its related parts. Principles to assist in initiating dialogue, reflective observation, seeing things within their context, building concepts, lifelong learning skills, and all these principles were re-enforced by authenticity. These principles were applied through a blended learning environment, consisting of face-to-face and online activities, using the learning management system.

Maybe this study did not bring anything new to some of us as educators, but it was new for students. What this article is calling for is nothing new, but something that was once part of our Islamic heritage. What is new, however, are the technologies that can offer us greater opportunities to exploit them in new ways for unravelling the minds of our students to face the wave of modern world challenges. I am not claiming that these are the only principles nor the only activities for seeing the whole, but I am claiming that in order to see the whole, one needs to take a different path. I think it would be nice one day for teachers in the Middle Eastern region to enter a classroom with students asking, "How are we going to learn?", instead of "What is going be in the exam?"

\section{Notes}

1. Fritjof Capra, "From the Parts to the Whole: Systems Thinking in Ecology and Education" (Berkeley CA: Center for Ecoliteracy, 1994), available online at http://www.hainescentre.com/pdfs/parts_ to_whole.pdf (accessed on 20 November 2010).

2. Peter Senge, The Fifth Discipline: The Art and Practice of the Learning Organization (New York: Currency and Doubleday, 1990).

3. Ibid. 
4. F. Kofman and P. Senge, "Communities of Commitment: The Heart of Learning Organisations", Organisation Dynamics 22, no. 3 (1993), 5-23.

5. J.G. Donlevy and T.R. Donlevy, "Teachers, Technology, and Training. Adult Education: A Brief Review of Literature Using a Template of Perspectives", International Journal of Instructional Media 25, no. 1 (1998), 1-10.

6. A. Bork, "Adult Education, Lifelong Learning, and the Future", Campus-Wide Information Systems 18 , no. 5 (2001), 195-203.

7. Ibid., 199.

8. Capra, "From the Parts".

9. [Abū Zakariyyā Muḥy al-Dīn Yaḥyā b. Sharaf al-Nawawī], "Imam An-Nawawi's Forty Hadiths", available online at http://www.40hadith.com/40hadith_en.htm (n.d.) (accessed on 20 November 2010) [English translation].

10. R. Yin, Case Study Research: Design and Methods (Beverly Hills CA: Sage Publications, 1994).

11. J.W. Creswell, Qualitative Inquiry and Research Design: Choosing Among Five Traditions (Beverly Hills CA: Sage Publications, 1998).

12. M. van Manen, Researching Lived Experience: Human Science for an Action Sensitive Pedagogy (London [Ontario, Canada]: Althouse Press, University of Western Ontario, 1990).

13. [al-Nawawī], "Forty Hadiths", narrated by Muslim.

14. Ibn Ḥajar al-'Asqalānī, "Preparing for the Day of Judgment", (n.d.) available online at http://www. scribd.com/doc/18792610/Preparing-for-the-Day-of-Judgement-by-Imam-Ibn-Hajar-AlAsqalaniPDF (accessed on 20 November 2010) [English translation].

15. Capra, "From the Parts", 6.

16. Qur'ān: 3:190-1;30:21

17. Ibn Khaldūn, The Muqaddimah: An Introduction to History, transl. Franz Rosenthal, Bollingen Series XLIII (Princeton: Princeton University Press, 1967).

18. P.M. Senge, "Mental Models", Planning Review 20, no. 2 (1992), 4-15.

19. Capra, "From the Parts", 5.

20. B. Van Oers, "From Context to Contextualizing", Learning and Instructions 8, no. 6 (1998), 481.

21. E.D. Hirsch, Validity in Interpretation (New Haven and London: Yale University Press, 1967), 47.

22. T.J. Conlon, "A Review of Informal Learning Literature: Theory and Implications for Practice in Developing Global Professional Competence", Advances in Developing Human Resources 28, nos. 2-3 (2004), 283-95.

23. Ibid.

24. V. Marsick and F. Volpe, Informal Learning on the Job: Advances in Developing Human Resources (San Francisco: Berrett-Koehler, 1999).

25. K. Demetrious, "Finding Voices: Authentic Learning Online in the Field of Public Communication and Citizenship", Prism 2, no. 1 (2004), 7.

26. S.D. Brookfield, The Skillful Teacher: On Technique, Trust, and Responsiveness in the Classroom (San Francisco: Jossey-Bass, 1990).

27. A. Cranton and E. Carusetta, "Perspectives on Authenticity in Teaching", Adult Education Quarterly 55, no. 1 (2004), 7.

28. A. Kraak (ed.), Changing Modes: New Knowledge Production and Its Implications for Higher Education in South Africa (Pretoria: Human Sciences Research Council, 2000), 53.

29. H. Astleitner, "Teaching Critical Thinking Online", Journal of Instructional Psychology 29, no. 2 (2002), 53-76.

30. K. Bruning, "The Role of Critical Thinking in the Online Learning Environment", Instructional Technology and Distance Learning 2, no. 5 (2005), 15-25.

31. S. Jones and L. Brown, "Alternative Views on Defining Critical Thinking through the Nursing Process", Holistic Nurse Practitioner 7 (1993), 71-6.

32. G. Walker, "Critical Thinking in Asynchronous Discussions", International Journal of Instructional Technology and Distance Learning 2, no. 6 (2005), 15-21.

33. For further information see http://moodle.org/ (accessed on 20 November 2010). 
34. M. McMahon, "Social Constructivism and the World Wide Web: A Paradigm for Learning", ASCILITE conference paper, Perth, Australia, 1997, available online at http://www.ascilite.org. au/conferences/perth97/papers/Mcmahon/Mcmahon.html (accessed on 20 November 2010); R.S. Prawat and R.E. Floden, "Philosophical Perspectives on Constructivist Views of Learning", Educational Psychologist 29, no. 1 (1994), 37-48.

35. For further information see http://en.wikipedia.org/wiki/Wiki (accessed on 20 November 2010).

36. V.P. Dennen, "From Message Posting to Learning Dialogues: Factors Affecting Learner Participation in Asynchronous Discussion", Distance Education 26, no. 1 (2005), 127-48.

37. B. Muirhead, "Relevant Assessment Strategies for Online Colleges and Universities", USDLA Journal 16, no. 1 (2002), available online at http://www.usdla.org/html/journal/FEB02_Issue/ article04.html (accessed on 20 November 2010); C. MacKnight, "Teaching Critical Thinking Through Online Discussions", Educause 23, no. 4 (2000), 38-41. 